Mеталлофиз. новейшие технол. / Metallofiz. Noveishie Tekhnol. (C) 2015 ИМФ (Институт металлофизики 2015 , т. 37 , № 1 , сс. 115-120

Оттиски доступны непосредственно от издателя

им. Г. В. Курдюмова НАН Украины)

Фотокопирование разрешено только

Напечатано в Украине.

в соответствии с лицензией

PACSnumbers: 61.72.sd, 64.75.Lm, 68.47.Gh, 81.05.Je, 81.65.Mq, 82.30.Lp, 82.80.Ej

\title{
Thermodynamic Modelling of Oxide Conversion Processes for Metals of Life
}

\author{
O. I. Mikadze, J. I. Bagdavadze*, T. A. Dzigrashvili, \\ and N. I. Maisuradze \\ Georgian Technical University, \\ 77 Kostava Str., \\ 0175 Tbilisi, Georgia \\ "Ferdinand Tavadze Institute of Metallurgy and Materials Science, \\ 15 Kazbegi Ave., \\ 0160 Tbilisi, Georgia
}

In the presented work, the environmentally friendly production processes of pure metals via reduction from the respective oxides in the atmosphere of ultra-low oxidation potential ( $P_{\mathrm{O}_{2}}=10^{-16}-10^{-26}$ atm) are offered. We propose the formation of such an environment by injection of ethyl alcohol in the reactor and interaction of its vapour with oxygen. Such conditions promote dissociation of oxides of almost any kind. Using this method, the pure, socalled 'metals of life' are obtained: $\mathrm{Cu}, \mathrm{Fe}, \mathrm{Ni}$, and $\mathrm{Co}$, which are used in medicine as the essential nutrients. In the case of chromium conversion, this process is completed with the synthesis of carbide phases. Production of pure $\mathrm{Cr}$ is possible by using the similar methodology with the help of oxygen pump. For identification of the reduced products, an X-ray phase analysis is used. The purity of the converted products is characterized by spectrochemical analysis. The experimental data are in a good conformity with the thermodynamic calculations of optimal temperature ranges of conversion reactions and the ratio of the initial ingredients.

У запропонованій роботі розглянуто екологічно безпечні процеси одержання чистих металів шляхом їх відновлення з відповідних оксидів у атмосфері з ультранизьким окиснювальним потенціялом $\left(P_{\mathrm{O}_{2}}=10^{-16}-10^{-26}\right.$ атм.). Ми пропонуємо створення такого середовища інжекцією етилового спирту в замкнений контур реактора внаслідок взаємодії пари спирту з киснем. Такі умови сприяють дисоціяції оксидів майже будь-якого виду. Цією методою одержано так звані «метали життя»: $\mathrm{Cu}, \mathrm{Fe}, \mathrm{Ni}$ и Co, які використовуються в медицині як поживні нутрієнти. У випадку конверсії оксиду хрому процес завершується синтезою карбідних фаз. Одержання чистого $\mathrm{Cr}$ можливе застосуванням подібної методології за допомогою кисневої помпи. Ідентифікація продуктів конверсії відбувається рентґено- 
фазовою структурною аналізою, а їхня чистота контролюється спектрохемічною методою. Експериментальні дані добре узгоджуються з термодинамічними обчисленнями оптимальних температур конверсійних реакцій і молярних часток початкових інгредієнтів.

В предложенной работе рассмотрены экологически безопасные процессы получения чистых металлов путём их восстановления из соответствующих оксидов в атмосфере с ультранизким окислительным потенциалом ( $P_{\mathrm{O}_{2}}=10^{-16}-10^{-26}$ атм.). Мы предлагаем создание такой среды инжекцией этилового спирта в замкнутый контур реактора в результате взаимодействия паров спирта с кислородом. Такие условия способствуют диссоциации оксидов почти любого вида. Этим методом получены так называемые «металлы жизни»: $\mathrm{Cu}, \mathrm{Fe}, \mathrm{Ni}$ и $\mathrm{Co}$, применяемые в медицине как питательные нутриенты. В случае конверсии оксида хрома процесс завершается синтезом карбидных фаз. Получение чистого $\mathrm{Cr}$ возможно применением подобной методологии с помощью кислородного насоса. Идентификация продуктов конверсии происходит рентгенофазовым структурным анализом, а их чистота контролируется спектрохимическим методом. Экспериментальные данные находятся в хорошем согласии с термодинамическими вычислениями оптимальных температур конверсионных реакций и молярных долей начальных ингредиентов.

Key words: metals of life, oxides, ethyl alcohol, conversion.

(Received June 3, 2014; in final version, August 14, 2014)

\section{INTRODUCTION}

In contrast to the classical methods of metallurgical and chemical processing of ores connected with significant energy consumption and ecological stress, we would like to recommend a different, energy-saving and environmentally friendly technology affording production of pure 'metals of life' adopted in pharmaceutical industry [1]. These biologically active metals of life take up position side by side in the fourth period of the Periodic Table of elements: ${ }^{24} \mathrm{Cr},{ }^{25} \mathrm{Mn},{ }^{26} \mathrm{Fe},{ }^{27} \mathrm{Co},{ }^{28} \mathrm{Ni},{ }^{29} \mathrm{Cu}$, ${ }^{30} \mathrm{Zn}$. Content of most of them is negligible in the body, but absence of these elements leads to ailments. As a basis for the offered technology of pure metals, production from the corresponding oxides is the principal possibility of creating gas environments with ultra-low partial pressure of oxygen in the closed volume of a reactor [2]. The accessibility level of rarefaction of oxygen (up to $\cong 10^{-28} \mathrm{~atm}$ ) is significantly lower than dissociation tension of the oxides of any considered metals.

\section{EXPERIMENTAL}

Since the purity of converted products is altered depending on purity 
of initial materials (in our case, oxides), the basic oxide powders of the analytical purity $(>99.9 \%)$ is used. An installation for the creation and maintenance of partial pressure of oxygen $\left(P_{\mathrm{O}_{2}}\right)$ within the required range of $10^{-16}-10^{-26}$ atm had been designed by the authors and described recently in [3]. The dynamics of the abrupt decrease of $P_{\mathrm{O}_{2}}$ in the closed contour is a function of the reactor temperature and practically is in progress up to the depressurization temperature of the reactor material. The optimal consumption of the ethyl alcohol is $0.2 \mathrm{mg}$ per 1 litre of a closed atmosphere and its heating to $800^{\circ} \mathrm{C}$ provides fall of $P_{\mathrm{O}}$ to $10^{-22} \mathrm{~atm}$. Increase of operating temperatures up to $1500^{\circ} \mathrm{C}$ stipulates achievement of fine and deep rarefaction of oxygen, $\cong 10^{-28} \mathrm{~atm}$. In such conditions, dissociation of practically each oxide becomes possible. At the same time, duration of the exposure process at fixed temperature does not influence the level of $P_{\mathrm{O}_{2}}$, and the most possible rarity is achieved at given instant. $\mathrm{X}$-ray phase analysis of the converted oxides was performed using the HZG-4 diffractometer for $\mathrm{X}$-ray powder diffraction analysis. Diffraction patterns are obtained using the $\mathrm{Cu} K_{\alpha} \mathrm{X}$-rays $(\lambda=1.542 \AA)$. The complete thermodynamic analysis of the reductive processes for these oxides is performed using the ASTRA-4 software.

\section{RESULTS AND DISCUSSION}

A computer simulation of thermodynamic processes at general atmospheric pressure in the temperature range 1000-2000 $\mathrm{K}$ was performed in the case of $\mathrm{Cr}_{2} \mathrm{O}_{3}$. During the simulation, the mole correlation of the converted oxides and the reducing gas was chosen based on the following reaction:

$$
\mathrm{Cr}_{2} \mathrm{O}_{3(\mathrm{~cd})}+4.5 \mathrm{C}_{2} \mathrm{H}_{5} \mathrm{OH}_{\text {(gas) }} \text {. }
$$

Among the probable condensed (cd) components, the following were considered: $\mathrm{H}_{2} \mathrm{O}, \mathrm{C}, \mathrm{Cr}, \mathrm{Cr}_{2} \mathrm{O}_{3}, \mathrm{CrO}_{2}, \mathrm{CrO}_{3}, \mathrm{Cr}_{3} \mathrm{C}_{2}, \mathrm{Cr}_{7} \mathrm{C}_{3}$, and $\mathrm{Cr}_{23} \mathrm{C}_{6}$. Because of plenty of gaseous connections of $\mathrm{C}-\mathrm{H}-\mathrm{O}$ system, only some of them were specified: $\mathrm{Cr}, \mathrm{CrO}_{2}, \mathrm{Cr}_{2} \mathrm{O}_{3}, \mathrm{CrN}$, and $\mathrm{CrOH}$. The basic results of complete thermodynamic analysis are presented in the diagram. Concerning chromium conversion, it should be noted that we have not found any information on the complete thermodynamic analysis of $\mathrm{Cr}_{2} \mathrm{O}_{3}$ interaction with the ethyl alcohol.

As well known, chromium possesses such a high chemical sensitivity to oxygen that it oxidizes at $1000^{\circ} \mathrm{C}$ even in the condition of space evacuation, where $P_{\mathrm{O}_{2}} \cong 10^{-20}$ at [5]. Therefore, high temperature, ultra-low partial pressure of oxygen, and the increased consumption of the reducing agent are required for conversion of $\mathrm{Cr}_{2} \mathrm{O}_{3}$ (see reaction).

Preliminary thermodynamic analysis of alcohol dissociation showed 
that below $400 \mathrm{~K}$ gaseous methane, water vapour, and condensed carbon precipitate, while at $450 \mathrm{~K}$ a partial dissociation of the methane takes place, and the content of the condensed carbon increases and exceeds that of the condensed carbon available in the system.

Since carbon exists among the possible condensed components, it is highly probable to suppose that convenient conditions are created for effective conversion of the oxides to pure metals or their carbide phases. Figure 1 shows the results of the analysis only in the temperature range $1000-2000 \mathrm{~K}$ because dissociation of chromium oxide does not take place below $1300 \mathrm{~K}$. In the $\mathrm{Cr}_{2} \mathrm{O}_{3}$ conversion process above $1350 \mathrm{~K}$, condensed chromium carbide $\mathrm{Cr}_{3} \mathrm{C}_{2}$ occurs, amounts to $30 \%$ of the mass, and remains unchanged up to $2000 \mathrm{~K}$. The abrupt decrease of the condensed carbon content (from $\cong 20 \%$ to $\cong 0 \%$ ) indicates at its intensive consumption during the synthesis of $\mathrm{Cr}_{3} \mathrm{C}_{2}$ and is optimal for termination of the process.

In order to check the thermodynamic calculations, some relevant results on $\mathrm{NiO}, \mathrm{CoO}, \mathrm{CuO}$, and $\mathrm{Fe}_{2} \mathrm{O}_{3}$ conversions are shown in Table 1 as good examples of conversion of oxides of other metals of life [3]. However, the conversion process of chromium oxide completes via synthesis of carbide phases instead of precipitation of metal substrate. The matter is that in the case of ethyl alcohol injection, the presence of free carbon in the reaction zone causes the carbidization of conversed chromium.

As should be noted here, the constructed installation for conversion of oxides allows creating a gaseous environment in two different ways: 1 -using an oxygen pump [2], or 2-via injection of ethyl alcohol in the closed contour of the reactor [5]. In spite of the nearly, the same

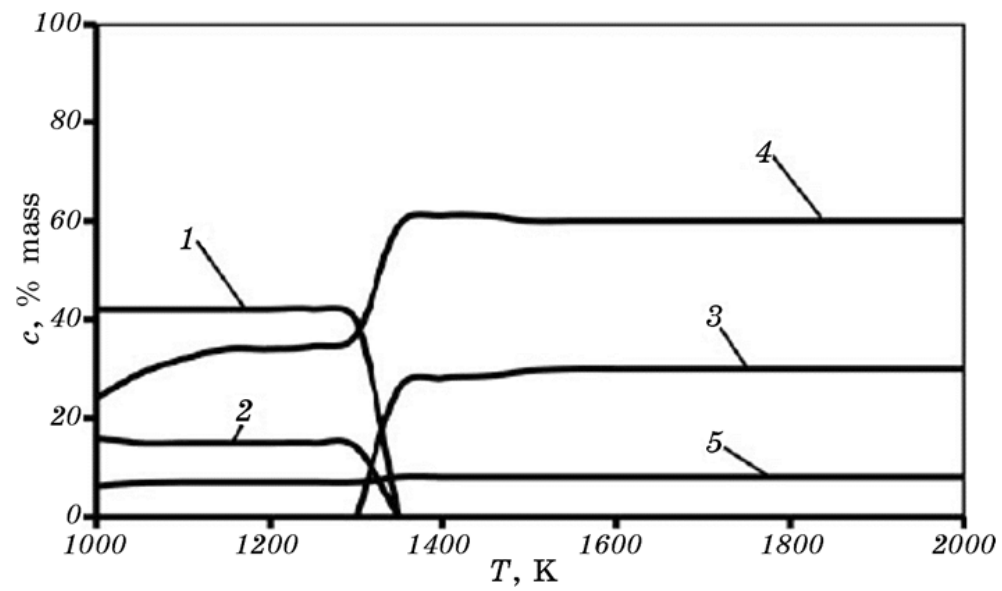

Fig. 1. Temperature dependence of the components concentration in the system: $1-\mathrm{Cr}_{2} \mathrm{O}_{3}, 2-\mathrm{C}, 3-\mathrm{Cr}_{3} \mathrm{C}_{2}, 4-\mathrm{CO}, 5-\mathrm{H}_{2} \mathrm{O}$. 
TABLE 1. Parameters of metal complete reduction from their oxides by alcohol injection method.

\begin{tabular}{c|c|c|c|c|c|c|c}
\hline \multirow{2}{*}{$\begin{array}{c}\text { Temperature, } \\
{ }^{\circ} \mathrm{C}\end{array}$} & $\begin{array}{c}\text { Partial pressure } \\
P_{\mathrm{O}_{2}}, \text { atm }\end{array}$ & \multicolumn{7}{|c}{ Duration, min } \\
\cline { 3 - 8 } & $10^{-21}$ & 1 & 5 & 10 & 15 & 20 & 60 \\
\hline 700 & $10^{-22}$ & & $\mathrm{NiO}$ & & $\mathrm{Fe}_{2} \mathrm{O}_{3}$ & & $\mathrm{CoO}$ \\
800 & $10^{-23}$ & & $\mathrm{NiO}$ & $\mathrm{CuO}$ & & & \\
900 & $10^{-24}$ & $\mathrm{NiO}$ & $\mathrm{CoO}$ & & & & \\
1000 & & & & & & & \\
\hline
\end{tabular}

TABLE 2. Parameters of metal complete reduction from their oxides by oxygen pump method.

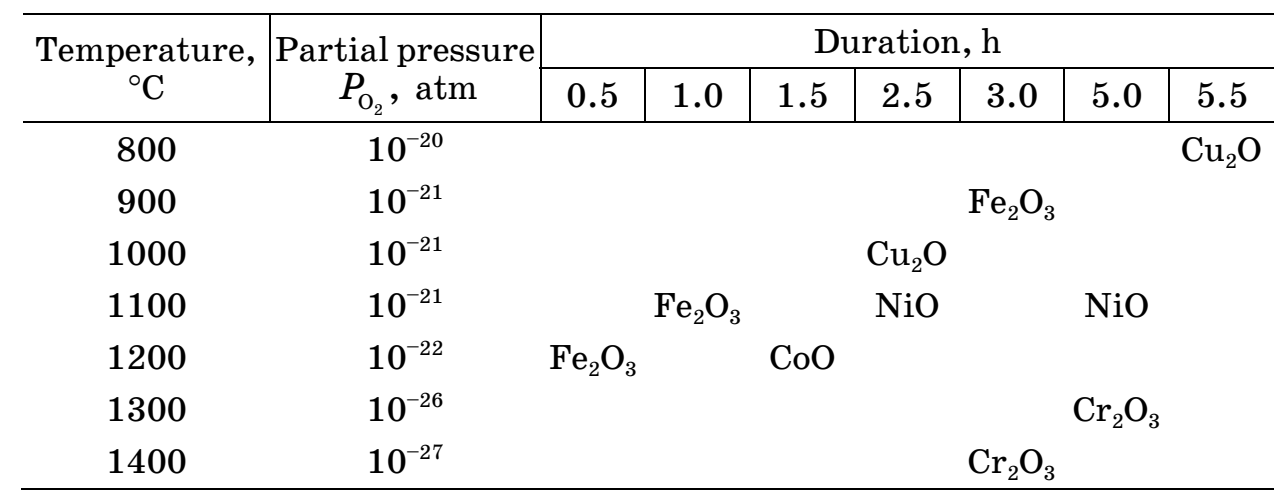

evacuation rate of oxygen in the reactor, the deoxidizing abilities of these methods are completely different (see Tables 1 and 2). As it is clear from the Tables, the conversion process accelerates when the atmosphere in the reactor is formed via injection of alcohols (Table 1). However, production of pure chromium is possible, if super-deep evacuation is achieved using oxygen pump (Table 2).

Taking into account the results shown in tables and the X-ray data, the obtained results on the complete thermodynamic analysis of chromium oxide conversion lead to the conclusion that the injection of ethyl alcohol is an efficient method for the formation of $\mathrm{Cu}, \mathrm{Ni}$, $\mathrm{Co}$, and $\mathrm{Fe}$ condensates, while in the case of chromium oxide, the end product of conversion is its carbide $-\mathrm{Cr}_{3} \mathrm{C}_{2}$, instead of pure metal (see Fig. 2).

\section{SUMMARY}

For the first time, it has been carried out a multicomponent thermody- 


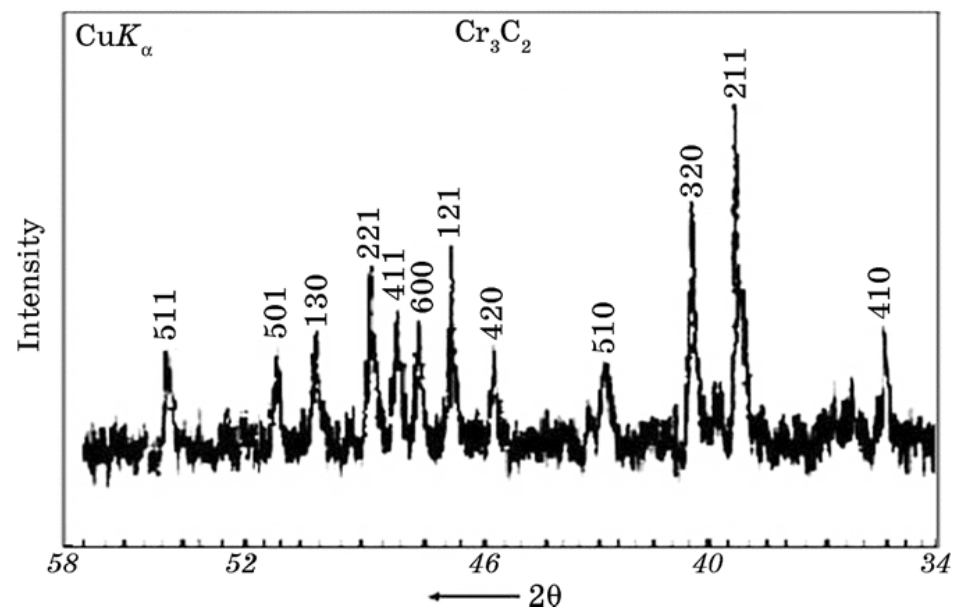

Fig. 2. XRD patterns of samples reduced at $1300^{\circ} \mathrm{C}$.

namic simulation of chromium conversion process using ethyl alcohol. It is determined that the highest output of conversion products correspond to the temperature range $1350-1600 \mathrm{~K}$. The molar ratio of chromium and ethyl alcohol is $1: 4.5$.

During conversion of the active carbide-forming metals oxides, the synthesis of carbide phases takes place simultaneously with their reduction. Production of such pure metal as chromium is possible using the oxygen pump.

\section{REFERENCES}

1. E. Terletsky, Metals, Which Are Always with You (Moscow: Znanie: 1986) (in Russian).

2. O. Mikadze, L. Rukhadze, and B. Bulia, Georgian Engineering News, 1: 90 (2000) (in Georgian).

3. O. Mikadze, A. Kandelaki, J. Bagdavadze, and L. Rukhadze, Bulletin of the Georgian National Academy of Sciences, 7, No. 1: 37 (2013).

4. N. Vatolin, G. Moiseyev, and B. Trusov, Thermodynamic Modelling in High-Temperature Inorganic Systems (Moscow: Metallurgy: 1994) (in Russian).

5. E. Gulbransen and K. Andrew, J. Electrochem. Soc., 99, No. 10: 402 (1952). 